\title{
Perplexing Questions About Novak's "Binary Soul Doctrine"
}

To the Editor:

The Journal recently carried a fascinating and lengthy paper by Peter Novak (2002) entitled "Division of the Self: Life After Death and the Binary Soul Doctrine." Novak submitted compelling evidence from 
throughout history to support the theory that we are indeed two-part creatures, comprised of a conscious mind and an unconscious mind. He went on to show how dreams, trances, and mystical experiences seem to indicate, with an almost uncanny reliability, that at death there is a split between the two minds: the conscious mind engaged in the initial experience (darkness or tunnel), then phasing out, perhaps to take on some type of residence in a "netherworld"; with the unconscious mind comprising the second phase of experience (lights, landscapes, spirit beings), seeming to ascend into higher orders beyond earthly life. And he especially connected his theory to research done on near-death experiences.

To say that Novak's research is impressive in the way he correlated stories, myths, and legends about death and the afterlife to a symbolic representation of left- and right-brain hemisphere functions would be an understatement. I think he is onto something worthy of further investigation. However, I would suggest caution in drawing any conclusions to his theory. The reason I say this is that there are too many missing pieces and contradictory elements to his data. Allow me to point out a few.

On page 164, Novak described the second stage of death (or neardeath) as being devoid of conscious thought and reason, with the individual accepting as truth whatever is presented. And he emphasized this assertion throughout his paper. In my book, Beyond the Light (1994), which he cited in his article, I included the story of Jeanie Dicus (pp. 57-61). The Dicus case refutes this assertion because, throughout her entire episode, she challenged the Jesus figure who appeared. She argued, questioned, disbelieved, and countered almost everything told to her. I was only able to include a fraction of her story; had I included the whole episode, the full extent of her demanding questions would have required an entire chapter. Just because an experiencer seems to be in a state of direct and certain knowing, does not mean everything given is accepted. In my own three near-death experiences, presented in brief in Chapter Two of Coming Back to Life (Atwater, 1988, pages 24-61), I reported how, in all three of my episodes, I often questioned, analyzed, reasoned, countered, explored, and investigated what was happening to me, as it occurred.

If I were to look back over the 23 years I have been involved in near-death research and estimate, based on my own case studies, how many experiencers accepted versus questioned what they encountered, I would offer this: child experiencers of near-death states frequently challenge greeters in the first phase of their experience. To an angelic 
figure they ask things like, "Is that what you really look like?" Yet they seldom argue with content in the second phase. With adult experiencers I have found the reaction to be quite the opposite: seldom do adults question greeters in the first phase, but quite often they will counter, challenge, or question the content and beings present in the content of the second phase. To give an idea of percentages from my research with those adult experiencers who in some way challenged or questioned the main content of their near-death episode, I would say one-third accepted verbatim everything presented to them, while the remaining two-thirds actively used their analytical abilities, some more than others.

Another assertion of Novak, and one quite common with many researchers, is that phase one consists of darkness or a tunnel and that those who do not report such a thing must have forgotten the occurrence. This is erroneous and does not hold up in broad-based research. The nationwide Gallup Poll on the subject of near-death experiences (Gallup and Proctor, 1982) found that only 9 percent reported a tunnel or any form of darkness. It was not until much later, after the media sensationalized the tunnel component, that more and more experiencers reported having experienced one during their episode. In my research on 3,000 adult experiencers and 277 child experiencers, hardly one-third claimed any such thing. Because of this, I no longer consider tunnels a signature feature of near-death states, but, rather, one of many elements associated with near-death states. In the majority of my cases, the first phase consisted either of an out-of-body experience or immersion into a brilliant light. I must admit, however, that with child experiencers, I did encounter quite a number of them who, in phase one, were met by "the living dark"-not darkness as we think darkness to be, but, rather, a warm and friendly intelligence some called "The Darkness That Knows."

On page 175, Novak wrote, "On its own, the unconscious could never choose to change its behavior patterns; it could never even grasp the fact that these behaviors were no longer capable of leading to fulfillment." If this is the state of mind that Novak characterizes for the second phase of a near-death experience, then I cannot imagine on what research he based that inference. It is typical, for both child and adult experiencers during their episode, to face misdeeds or any type of behavior that was less than satisfactory to them, and decide, right there and then, to make corrections. This is the reason many give for why they chose to return to life: to change their thinking and their actions.

His statement on page 176 about the contradiction in testimony from experiencers about time is really not a contradiction. Certainly, 
experiencers report, almost to a person, that in reality there is no such thing as time or space, that neither exists on "The Other Side." But in "getting there," in going through the stages leading to arrival, one does go through "timing" in the sense of sequences of events, one after another. What is actually reported by experiencers, at least the vast majority in my research base, is a scenario closer to a shift in dominance that appears to take place between soul and ego, than to anything akin to a splitting off of left-brain and right-brain functions. It is as if the ego personality dissolves into the fullness of the soul, the real self: the two become one. And this distinction is emphasized in vivid and compelling language. Because this distinction is such a strong one, I find myself uncomfortable with Novak's conclusions about the left brain comprising the totality of phase one and the right brain comprising phase two. I can appreciate why Novak would draw this conclusion based on the material he detailed, and it is an interesting concept. But his argument did not encompass all the evidence from near-death research, nor is it in line with the majority of experiencer accounts. Additionally, in the 1960s and early 1970s when I was actively involved in dehaunting houses, and on occasion since, I had many different encounters with ghosts, apparitions, and lost souls. Certainly, there were those who were little more than psychic residue, leftover energy imprinting from individuals long gone. Sometimes this residue could be traced to a living person who had simply moved away; sometimes it was connected to a death, as if strong emotions could hang in the air or permeate fabric and wood once expressed. On other occasions, the apparitions appeared and disappeared with a kind of rhythm, as if they were a recording stuck on replay. And with some there was no response, no change, nothing to indicate the presence of a soul. With others, however, there was response once engaged, and interactions followed-usually "rescue work" in the sense of helping the individual to realize he or she was dead and it was time to move on. A particular "release" of this nature that I did, which was written up in a local newspaper (Culbertson, 1989), centered around a Confederate soldier at Selma Mansion. The bulk of my cases were with fully responsive souls who, for differing reasons, refused to leave the earth plane. One encounter I had was with a 6-year-old boy standing at a freshly dug grave. The boy appeared to be a living child. I asked him what he was doing there. His audible answer was: "My Mommy and Daddy told me never to go anywhere without their permission." On further questioning, I learned that he had been hit by a car on the way to school and that it was his body in the grave. I looked at the headstone and discovered that what the youngster had told me 
was true. I was rather startled at first, then saddened. Try as I may, I could not convince him it was all right to move on into the light realms. He stubbornly refused to budge without his parents' permission. I went home and held a prayer service for him, affirming and knowing that what was needed to help him would occur. The next day I went back to the cemetery and the boy was gone. This "ghost" was hardly a mindless apparition.

Yes, many ghosts are indeed zombie-like thought forms or psychic residue. But others are living souls who could use a little extra help. To wield the same brush stroke while painting them all into the same picture is unwise.

\section{References}

Atwater, P. M. H. (1988). Coming back to life: The after-effects of the near-death experience. New York, NY: Dodd, Mead.

Atwater, P. M. H. (1994). Beyond the light: What isn't being said about the near-death experience. New York, NY: Birch Lane Press.

Culbertson, C. (1989, June 27). Confederate soldier "released" from earthly bonds. The News Virginian [Staunton, VA], pp. 1 and 6.

Gallup, G., and Proctor, W. (1982). Adventures in immortality: A look beyond the threshold of death. New York: NY: McGraw-Hill.

Novak, P. (2002). Division of the self: Life after death and the binary soul doctrine. Journal of Near-Death Studies, 20, 143-189.

P. M. H. Atwater, L.H.D.

P.O. Box 7691

Charlottesville, VA 22906-7691

e-mail: atwater@cinemind.com 